\title{
Predicting CBR Values of Black Cotton Soil Stabilized with Cement and Waste Glass Admixture Using Regression Model
}

\author{
Ibrahim Abdulkarim Ikara ${ }^{1,}$, Ali Musa Kundiri², Abbagana Mohammed ${ }^{1}$ \\ ${ }^{1}$ Department of Civil Engineering, Abubakar Tafawa Balewa University, Bauchi, Bauchi State, Nigeria \\ ${ }^{2}$ Department of Civil and Water Resource Engineering, University of Maidugri, Maiduguri, Borno State, Nigeria \\ Email address \\ iaikara12@gmail.com (I. A. Ikara), alikundilri@yahoo.com (A. M. Kundiri), abbaganam@gmail.com (A. Mohammed) \\ ${ }^{*}$ Corresponding author
}

\section{To cite this article:}

Ibrahim Abdulkarim Ikara, Ali Musa Kundiri, Abbagana Mohammed. Predicting CBR Values of Black Cotton Soil Stabilized with Cement and Waste Glass Admixture Using Regression Model. American Journal of Traffic and Transportation Engineering.

Vol. 4, No. 1, 2019, pp. 31-36. doi: 10.11648/j.ajtte.20190401.15

Received: March 7, 2019; Accepted: April 22, 2019; Published: May 15, 2019

\begin{abstract}
In highway constructions, sub-grade and sub-base soil stabilization has been used as one of the prime and major process for many years in order to improve the engineering properties of soil. The strength of theses layers is indicated by their California bearing ratio (CBR) value which is quite expensive and time consuming. In order to overcome this situation, this study presents a methodology for predicting soaked California Bearing Ration (CBR) value of Black Cotton Soil Stabilized with Cement and Waste Glass Admixture using Multiple Regression Analysis (MRA). Experimental test results such Atterberg limit (Liquid limit (LL), Plastic limit (PL) and Plasticity index (PI)), Compaction characteristics of two compactive efforts namely standard proctor (SP) and modified proctor (MP) (maximum dry density (MDD) and optimum moisture content $(\mathrm{OMC})$ ), CBR, Waste glass (WG) content and Cement content $(\mathrm{Cm})$, obtained from a laboratory at Abubakar Tafawa Balewa University Bauchi, Nigeria, have been employed in developing multiple regression models. California Bearing Ration was taken as the dependent variables while Liquid limit, Plastic limit, maximum dry density, optimum moisture content, waste glass content and Cement content were taken as independent variables. The regression analysis calculated the error mean square $\left(\mathrm{MS}_{\mathrm{E}}\right)$ for each possible model, and models with large $\mathrm{MS}_{\mathrm{E}}$ were not selected for the best regression equations. The best models have a minimum value of $\mathrm{MS}_{\mathrm{E}}$ occurring for the six-variable model $\left(\mathrm{Cm}, \mathrm{WG}, \mathrm{LL}, \mathrm{PL}, \mathrm{OMC}_{\mathrm{sp}}, \mathrm{MDD}_{\mathrm{sp}}\right)$ and $\left(\mathrm{C}_{\mathrm{m}}, \mathrm{WG}\right.$, $\mathrm{PL}, \mathrm{LL}, \mathrm{OMC}_{\mathrm{mp}}, \mathrm{MDD}_{\mathrm{mp}}$ ) with a corresponding higher value of coefficient of multiple determination $\mathrm{R}^{2}=0.98$ and 0.94 . The performance evaluation of the fitted regression models indicates a strong correlation $\left(\mathrm{R}^{2}=0.89-0.98\right)$ between the mentioned variables, and the model equations developed from this work provided a very good prediction of the response, as the equations can be employed for making estimates of soaked CBR of other black cotton soils having similar geotechnical properties.
\end{abstract}

Keywords: Soil Stabilization, Black Cotton Soil, Waste Glass Admixture, Regression Models

\section{Introduction}

In order to improve the strength properties of Black cotton soil, several types of stabilized materials are used as base courses, sub-base courses, or treated sub-grade for highway pavements, [1]. These include cement stabilized or treated aggregate, soil cement, lime-cement fly-ash, and limestabilized materials. Typically, the CBR values of these materials is used for pavement design purpose.

Highway pavement is a relatively stable supper-imposed layers of materials, constructed over the natural soil for supporting and distributing wheel loads and providing durable wearing surface for transportation and economic development of a country, [2]. The flexible pavement is most favoured in almost all developing nations such as Nigeria. The Design and performance of flexible pavement mainly depends on the strength of the sub-grade material, the load from the pavement surface is ultimately transferred to subbase and to the sub- grade, [3]. The California bearing ratio (CBR) test is an empirical method used in design of flexible 
pavement, it determines the thickness of the pavement, in other words, sub grade with lower CBR value will have relatively thicker pavement compared to the sub grade that has higher CBR value [3]. Hence, the suitability and stability of sub-grade material need to be evaluated before the construction of pavements.

Various researchers such as Satyanarayana \& Pavani, Gregory \& Cross, Vinod \& Reena, Patel \& Desai, and Yildrim \& Gunaydin have developed models for estimating the CBR values on the basis of low cost, less time consumption and easiness to carry out such tests [48]. Some other researchers like Patel \& Patel, Venkatasubramanian \& Dhinakaran, Sabat, Alawi \& Rajab and Talukdar also developed multiple liner regression analysis models (MLRA) for correlating the $C B R$ with index properties of soil using soft computing systems like Artificial Neural Networks (ANN) and gene expression programming (GEP) [9-13].

Previous research by [14] has shown the potential of using cement stabilized Black cotton soil with Waste Glass (WG) admixture as a subgrade layer. This study, is aimed at using the application of multiple regression method for the estimation of soaked CBR by reliably correlating the soaked CBR value of cement stabilized Black cotton soil with Waste Glass (WG) admixture, using index properties like, Plasticity Characteristics (LL and PL), Compaction Characteristics (MDD and OMC), WG and cement content (Cm), so as to be able to take care of the effect of the stabilizer and the admixture in the regression.

\section{Methodology}

However, to conduct a CBR test, representative soil sample has to be collected from the selected location, from which a remoulded specimen has to be prepared at predetermined optimum moisture content (OMC) and maximum dry density (MDD) with standard or modified proctor compaction energy as the case may be, for the test to be conducted. To obtain the soaked CBR value of a soil sample, it takes at least 48 hours making CBR test expensive, time consuming and laborious [2]. As a result, only a limited number of CBR tests could be performed per kilometer length of a proposed road to be constructed. Similarly, in a situation where stabilization is required, such limited number of CBR test results may not generally reveal the variation in the $\mathrm{CBR}$ values over the length of the road that need stabilizing to enable rational, economic and safe construction [2]. This could be avoided only if a large number of soil sample are taken along the length of the road. But such a procedure will increase project cost and time. To overcome this problem a simple and less time-consuming approach is necessary, this can be done by correlating soaked CBR value with easily determining soil parameters.

Twenty (20) disturbed soil samples stabilized with the required Ordinary Portland cement (OPC) with WG blend at OMC were prepared. The prepared soil/OPC/WG blend samples were tested for soaked CBR value, OMC, MDD, LL, PL, and PI. These tests were performed in accordance with BS 1377 [15] for natural soil and BS 1924 [16] for the stabilized soil, using the standard proctor (SP) and modified proctor (MP) compactive efforts.

MINITAB 16.1, statistical software was used to develop the regression models for the data. The CBR was used as the dependent variables, while MDD, WG, Cm, LL and PL were used as independent variables.

The general multiple linear regression model is given equation 1, and the fitted equation is presented in equation 2.

$$
Y=\beta_{0}+\beta_{1} X_{1}+\cdots+\beta_{k} X_{k}+e
$$

The fitted equation:

$$
\widehat{Y}=b_{0}+b_{1} x_{1}+\cdots+b_{k} x_{k}
$$

Where: $\mathrm{Y}=$ response, $\mathrm{X}_{\mathrm{k}}=\mathrm{k}^{\text {th }}$ predictor,

$\beta_{\mathrm{k}}=\mathrm{k}^{\text {th }}$ population regression coefficient, $\mathrm{e}=$ error term, $\mathrm{b}_{\mathrm{k}}$ $=$ estimate of $\mathrm{k}^{\text {th }}$ population regression coefficient, $\hat{Y}=$ fitted response

\section{Results and Discussion}

The result of the laboratory prepared soil/OPC/WG blend samples are shown in Table 1. The results based on the geotechnical parameters were used to develop regression models using multiple linear regression analysis (MLRA). The ranges of soil/OPC/WG blend properties studied in this investigation were: $\mathrm{WG}=0-20 \%, \mathrm{Cm}=2-8 \%, \mathrm{LL}=47.1$ $59.8 \%, \mathrm{PL}=31-36.3 \%, \mathrm{MDD}=1.47-1.63$ and $1.55-$ $1.76 \mathrm{Mg} / \mathrm{m}^{3}$ for SP and MP, OMC $=19.8-25.4$ and $17.6-$ $23 \%$ for SP and MP with corresponding soaked CBR values $=9.1-20.4$ and $16-29.3 \%$ for SP and MP compactive effort, as shown in Table 1. The entire range of parameters are selected for the regression analysis to predict the soaked CBR value.

For a reliable prediction model, the model should possess a high value of $\mathrm{R}^{2}$ and have a low value of $\mathrm{MS}_{E}$ [17] The regression analysis calculated the error mean square $\left(\mathrm{MS}_{E}\right)$ for each possible model, and models with large $\mathrm{MS}_{E}$ were not selected for the best regression equations in order to obtain a reliable model. The $\mathrm{MS}_{E}$ is a measure of the units of the response variable and represents the standard distance values that fall from the fitted values. Therefore, the lower the $\mathrm{MS}_{E}$ the better the model predicts the response and the Coefficient of multiple determination $\left(\mathrm{R}^{2}\right)$ describes the amount of variation in the observed response values by the predictor(s). The higher the value of $\mathrm{R}^{2}$, the better the model fits the data. By and large, only models with small values of $\mathrm{MS}_{\mathrm{E}}$ were examined in detail. Tables 2 and 3 , gives the list of all possible regressions for the 20 observations listed in Table 1. 
Table 1. Laboratory test results of prepared soil/OPC/WG blend samples.

\begin{tabular}{|c|c|c|c|c|c|c|c|c|c|c|c|c|}
\hline \multirow{2}{*}{$\mathbf{S} / \mathbf{n}$. } & \multicolumn{3}{|c|}{ Replacement proportion by dry weight of soil (\%) } & \multicolumn{3}{|c|}{ Index properties (\%) } & \multicolumn{2}{|c|}{$\operatorname{MDD}\left(\mathrm{Mg} / \mathrm{m}^{3}\right)$} & \multicolumn{2}{|c|}{ OMC (\%) } & \multicolumn{2}{|c|}{ Soaked CBR (\%) } \\
\hline & SOIL & OPC & WG & $\mathbf{L L}$ & PL & PI & SP & MP & SP & MP & SP & MP \\
\hline 1 & 98 & 2 & 0 & 59.8 & 31 & 28.8 & 1.47 & 1.55 & 25.4 & 23 & 9.1 & 16 \\
\hline 2 & 96 & 4 & 0 & 57 & 32.3 & 24.7 & 1.53 & 1.57 & 24.1 & 22.2 & 12 & 20 \\
\hline 3 & 94 & 6 & 0 & 53 & 33.6 & 19.4 & 1.59 & 1.64 & 23.7 & 21.1 & 13 & 21.7 \\
\hline 4 & 92 & 8 & 0 & 49.9 & 35.1 & 14.8 & 1.61 & 1.66 & 21.9 & 20 & 16 & 25 \\
\hline 5 & 93 & 2 & 5 & 55.5 & 31.4 & 24.1 & 1.53 & 1.66 & 24.7 & 20.6 & 9 & 16.7 \\
\hline 6 & 88 & 2 & 10 & 53.3 & 32.3 & 21 & 1.57 & 1.68 & 23.1 & 19.5 & 9.6 & 18 \\
\hline 8 & 78 & 2 & 20 & 51.4 & 33.1 & 18.3 & 1.62 & 1.69 & 20.2 & 18.9 & 12.5 & 20.1 \\
\hline 9 & 91 & 4 & 5 & 54.3 & 33.2 & 21.1 & 1.57 & 1.69 & 23.7 & 20 & 12.4 & .9 \\
\hline 10 & 86 & 4 & 10 & 52.7 & 34.1 & 18.6 & 1.58 & 1.69 & 22.9 & 19.2 & 12.8 & 21.4 \\
\hline 11 & 81 & 4 & 15 & 52 & 34.9 & 17.7 & 1.59 & 1.71 & 21.7 & 19.3 & 14.3 & .1 \\
\hline 12 & 76 & 4 & 20 & 51.6 & 35.7 & 15.9 & 1.62 & 1.72 & 20.1 & 18.7 & 14.7 & 23.7 \\
\hline 13 & 89 & 6 & 5 & 50.3 & 33.8 & 16.5 & 1.60 & 1.71 & 22.8 & 19 & 14 & 22.8 \\
\hline 14 & 84 & 6 & 10 & 48.9 & 34.8 & 14.1 & 1.61 & 1.71 & 22.1 & 18.9 & 15.1 & 23 \\
\hline 17 & 87 & 8 & 5 & 49.2 & 34.6 & 14.6 & 1.61 & 1.73 & 21.4 & 18.5 & 17.1 & 26 \\
\hline 18 & 82 & 8 & 10 & 48.2 & 35.2 & 13 & 1.62 & 1.73 & 20.6 & 18.3 & 7.9 & 26.8 \\
\hline 19 & 77 & 8 & 15 & 48.3 & 35.9 & 12.4 & 1.61 & 1.75 & 20.9 & 17.9 & 18.7 & 27 \\
\hline 20 & 72 & 8 & 20 & 47.1 & 36.3 & 10.8 & 1.63 & 1.76 & 19.8 & 17.6 & .4 & 29.3 \\
\hline
\end{tabular}

Table 2. Regression variables for Standard Proctor compactive effort.

\begin{tabular}{|c|c|c|c|c|c|c|}
\hline $\mathbf{S} / \mathbf{n}$ & No. of variables in model & Variables in model & $\mathrm{SS}_{\mathrm{R}}(\mathrm{p})$ & $\mathrm{SS}_{\mathrm{E}}(\mathrm{p})$ & $\mathbf{M S}_{\mathrm{E}}(\mathbf{p})$ & $\mathbf{R}^{2}$ \\
\hline 1 & 3 & $\mathrm{Cm}, \mathrm{WG}, \mathrm{LL}$ & 110.870 & 72.860 & 4.554 & 0.63 \\
\hline 2 & 3 & $\mathrm{Cm}, \mathrm{WG}, \mathrm{PL}$ & 140.426 & 43.303 & 2.706 & 0.76 \\
\hline 3 & 3 & $\mathrm{Cm}, \mathrm{WG}, \mathrm{OMCsp}$ & 163.274 & 20.455 & 1.131 & 0.89 \\
\hline 4 & 3 & $\mathrm{Cm}, \mathrm{WG}, \mathrm{MDDsp}$ & 110.552 & 73.177 & 4.574 & 0.60 \\
\hline 5 & 4 & $\mathrm{Cm}, \mathrm{WG}, \mathrm{LL}, \mathrm{PL}$ & 162.265 & 21.465 & 1.431 & 0.88 \\
\hline 6 & 4 & Cm, WG, LL, OMCsp & 160.852 & 22.878 & 1.525 & 0.86 \\
\hline 7 & 4 & Cm, WG, LL, MDDsp & 121.934 & 61.795 & 4.120 & 0.66 \\
\hline 9 & 5 & Cm, WG, LL, PL, MDDsp & 162.345 & 21.385 & 1.527 & 0.88 \\
\hline 10 & 6 & Cm, WG, LL, PL, OMCsp, MDDsp & 180.149 & 3.580 & 0.275 & 0.98 \\
\hline
\end{tabular}

Table 3. Regression variables for Modified Proctor compactive effort.

\begin{tabular}{|c|c|c|c|c|c|c|}
\hline $\mathbf{S} / \mathbf{n}$ & No.of variables in model & Variables in model & $\mathrm{SS}_{\mathrm{R}}(\mathrm{p})$ & $\mathbf{S S}_{\mathrm{E}}(\mathbf{p})$ & $\mathbf{M S}_{\mathrm{E}}(\mathbf{p})$ & $\mathbf{R}^{2}$ \\
\hline 1 & 3 & $\mathrm{Cm}, \mathrm{WG}, \mathrm{LL}$ & 154.374 & 82.968 & 5.186 & 0.65 \\
\hline 2 & 3 & $\mathrm{Cm}, \mathrm{WG}, \mathrm{PL}$ & 183.028 & 54.314 & 3.395 & 0.77 \\
\hline 3 & 3 & $\mathrm{Cm}, \mathrm{WG}, \mathrm{OMCmp}$ & 156.166 & 81.176 & 5.073 & 0.66 \\
\hline 4 & 3 & $\mathrm{Cm}, \mathrm{WG}, \mathrm{MDDmp}$ & 130.801 & 106.541 & 6.659 & 0.55 \\
\hline 5 & 4 & $\mathrm{Cm}, \mathrm{WG}, \mathrm{LL}, \mathrm{PL}$ & 209.539 & 27.803 & 1.854 & 0.88 \\
\hline 6 & 4 & $\mathrm{Cm}, \mathrm{WG}, \mathrm{LL}, \mathrm{OMCmp}$ & 166.331 & 71.011 & 4.734 & 0.70 \\
\hline 7 & 4 & $\mathrm{Cm}, \mathrm{WG}, \mathrm{LL}, \mathrm{MDDmp}$ & 162.019 & 75.323 & 5.022 & 0.68 \\
\hline 9 & 5 & $\mathrm{Cm}, \mathrm{WG}, \mathrm{LL}, \mathrm{PL}, \mathrm{MDDmp}$ & 211.331 & 26.011 & 1.858 & 0.89 \\
\hline 10 & 6 & Cm, WG, PL, LL, OMCmp, MDDmp & 223.582 & 13.760 & 1.058 & 0.94 \\
\hline
\end{tabular}

Where: $\mathrm{SS}_{\mathrm{R}}=$ regression sum of squares; $\mathrm{SS}_{\mathrm{E}}=$ error sum of squares; $\mathrm{SS}_{\mathrm{T}}=$ total sum of squares; $\mathrm{MS}_{\mathrm{R}}=$ regression mean square; $\mathrm{MS}_{\mathrm{E}}=$ error mean square

In terms of $R^{2}$ improvement, there is an average gain in going from a three-variable model to a six-variable model, with the several models having good values of $\mathrm{MS}_{E}$. The best models have a minimum value of $\mathrm{MS}_{E}$ occurring for the sixvariable model $\left(\mathrm{Cm}, \mathrm{WG}, \mathrm{LL}, \mathrm{PL}, \mathrm{OMC}_{\mathrm{sp}}, \mathrm{MDD}_{\mathrm{sp}}\right)$ and $\left(\mathrm{C}_{\mathrm{m}}\right.$, $\left.\mathrm{WG}, \mathrm{PL}, \mathrm{LL}, \mathrm{OMC}_{\mathrm{mp}}, \mathrm{MDD}_{\mathrm{mp}}\right)$ with a corresponding higher value of coefficient of multiple determination for both SP and MP compactive efforts i.e 0.98 and 0.94. Even though, other models have small values of $\mathrm{MS}_{E}$, those with high values of $\mathrm{R}^{2}$ were also considered for validation. Such other models include; (Cm, WG, LL, PL, OMCsp), (Cm, WG, LL, PL, OMCmp), (Cm, WG, LL, PL, MDDmp) and ( $\mathrm{C}_{\mathrm{m}}, \mathrm{WG}$, $\mathrm{OMC}_{\mathrm{sp}}$ ). According to [18], the closer the $\mathrm{R}^{2}$ value is to unity and the smaller the standard deviation, the better the model in predicting the response variable. Also, [19] noticed that large $\mathrm{R}^{2}$ (near unity) are considered good in model development. The equations obtained from the regression of the above models are presented in Table 4. 
Table 4. Best equations obtained from the regression models.

\begin{tabular}{|c|c|c|c|c|}
\hline Equation No. & Variables in model & Model equation & $\mathbf{M S}_{\mathrm{E}}(\mathbf{p})$ & $\mathbf{R}^{2}$ \\
\hline 1 & Cm, WG, OMCsp & CBRsp $=59.5+0.239 \mathrm{Cm}-0.187 \mathrm{WG}-2.03$ OMCsp & 1.131 & 0.89 \\
\hline 2 & $\mathrm{Cm}, \mathrm{WG}, \mathrm{LL}, \mathrm{PL}, \mathrm{OMCsp}$ & CBRsp $=0.7-0.356 \mathrm{Cm}-0.189 \mathrm{WG}-0.088 \mathrm{LL}+1.37 \mathrm{PL}-1.13 \mathrm{OMCsp}$ & 0.844 & 0.94 \\
\hline 3 & $\begin{array}{l}\text { Cm, WG, LL, PL, OMCsp, } \\
\text { MDDsp }\end{array}$ & $\begin{array}{l}\text { CBRsp }=108-0.464 \mathrm{Cm}-0.240 \mathrm{WG}-0.607 \mathrm{LL}+1.31 \mathrm{PL}-1.47 \text { OMCsp }- \\
\text { 44.4 MDDsp }\end{array}$ & 0.275 & 0.98 \\
\hline 4 & Cm, WG, LL, PL, OMCmp & $\mathrm{CBRmp}=-15.1-0.663 \mathrm{Cm}-0.270 \mathrm{WG}-0.411 \mathrm{LL}+2.20 \mathrm{PL}-0.517 \mathrm{OMCmp}$ & 1.908 & 0.89 \\
\hline 5 & Cm, WG, LL, PL, MDDmp & $\mathrm{CBRmp}=19.5-0.836 \mathrm{Cm}-0.178 \mathrm{WG}-0.759 \mathrm{LL}+2.33 \mathrm{PL}-18.5 \mathrm{MDDmp}$ & 1.858 & 0.89 \\
\hline 6 & $\begin{array}{l}\text { Cm, WG, PL, LL, OMCmp, } \\
\text { MDDmp }\end{array}$ & $\begin{array}{l}\mathrm{CBRmp}=151-1.05 \mathrm{Cm}-0.152 \mathrm{WG}+2.32 \mathrm{PL}-0.935 \mathrm{LL}-1.66 \mathrm{OMCmp}- \\
71.6 \mathrm{MDDmp}\end{array}$ & 1.058 & 0.94 \\
\hline
\end{tabular}

The model validation assessment determines the degree to which a model is an accurate representation of the experimental data.

In validating the models, predicted values were computed using the best model equations i.e Eqn. 1-6 and plotted against number of samples, similarly, experimental data were also plotted against number of samples and comparison is made as presented in figures 1-6. It could be observed from the figures that the experimental values are close to the predicted values, which is evident from the plot which showed the same trend as could be seen from the values of the $\mathrm{R}^{2}$ trends.

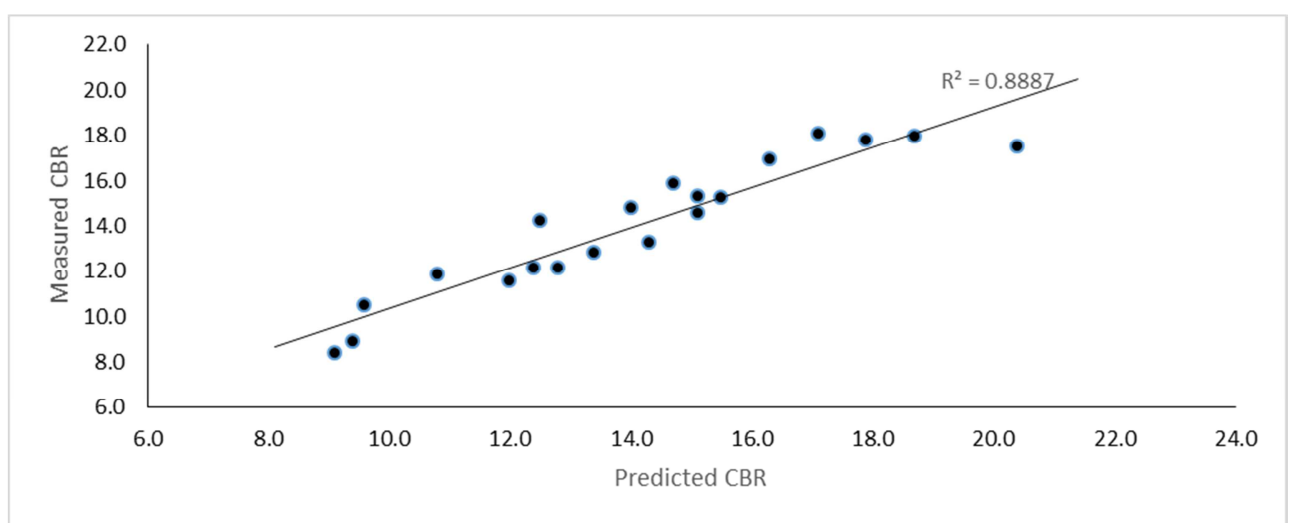

Figure 1. Validation plot of CBRsp $=59.5+0.239 \mathrm{Cm}-0.187 \mathrm{WG}-2.03 \mathrm{OMCsp}$.

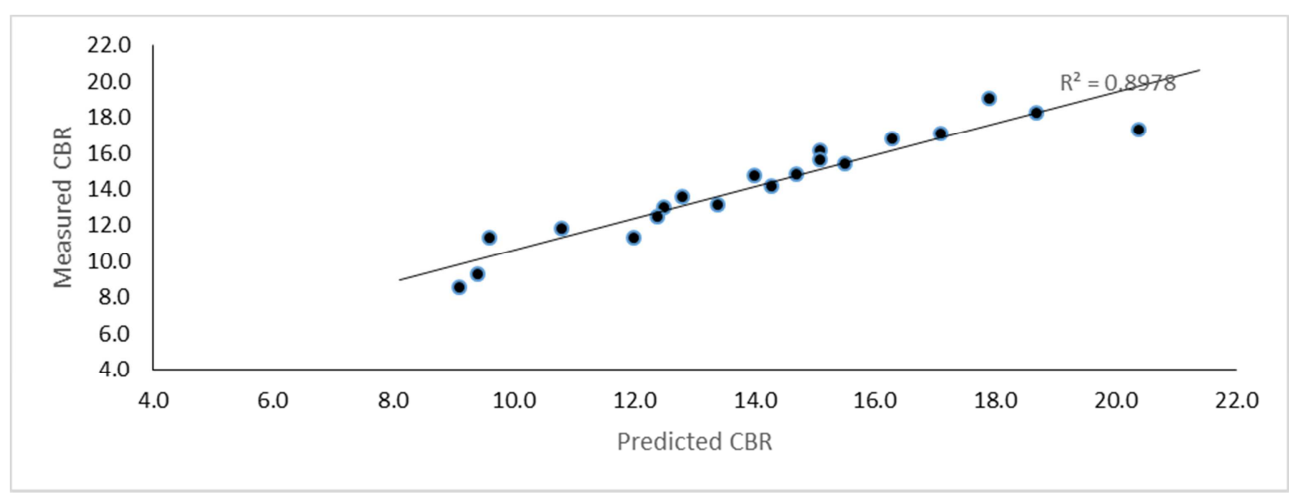

Figure 2. Validation plot of CBRsp $=0.7-0.356 \mathrm{Cm}-0.189 \mathrm{WG}-0.088 \mathrm{LL}+1.37 \mathrm{PL}-1.13$ OMCsp.

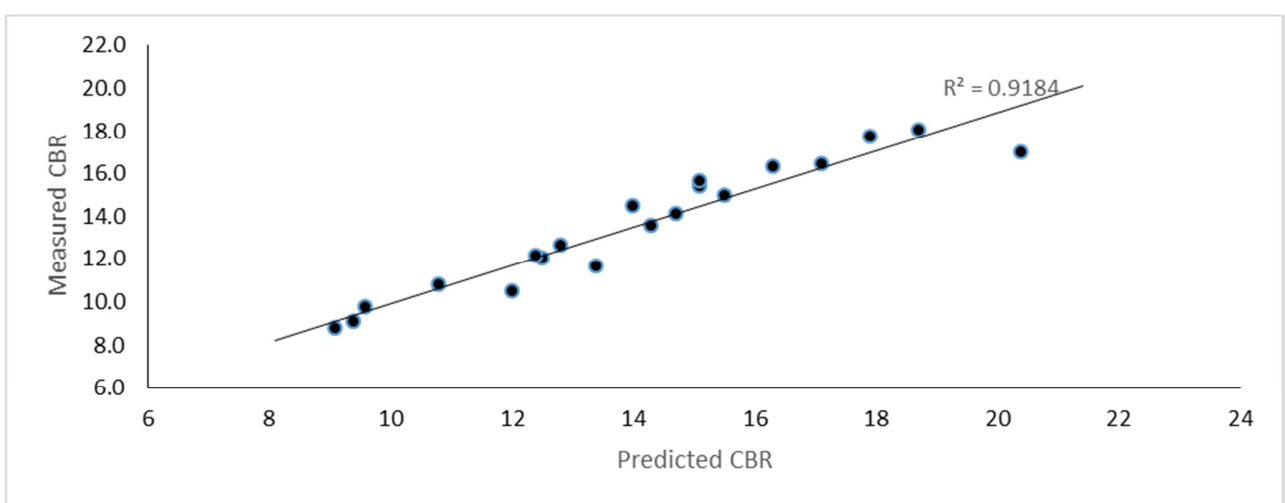

Figure 3. Validation plot of CBRsp $=108-0.464 \mathrm{Cm}-0.240 \mathrm{WG}-0.607 \mathrm{LL}+1.31 \mathrm{PL}-1.47 \mathrm{OMCsp}-44.4 \mathrm{MDDsp}$. 


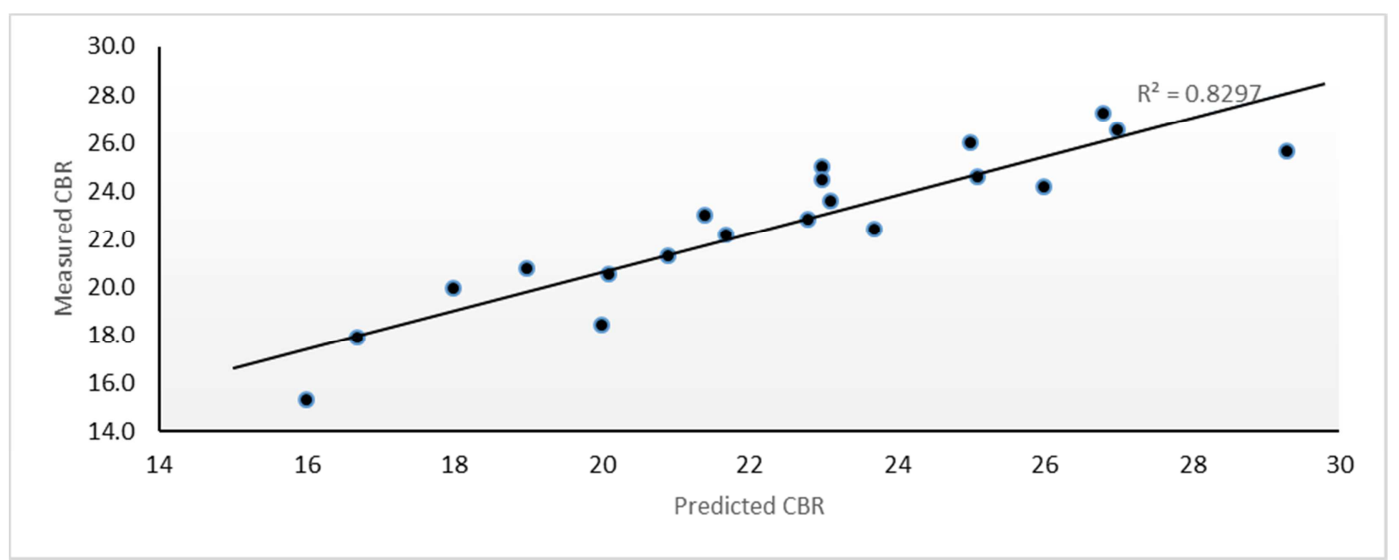

Figure 4. Validation plot of CBRmp $=-15.1-0.663 \mathrm{Cm}-0.270 \mathrm{WG}-0.411 \mathrm{LL}+2.20 \mathrm{PL}-0.517$ OMCmp.

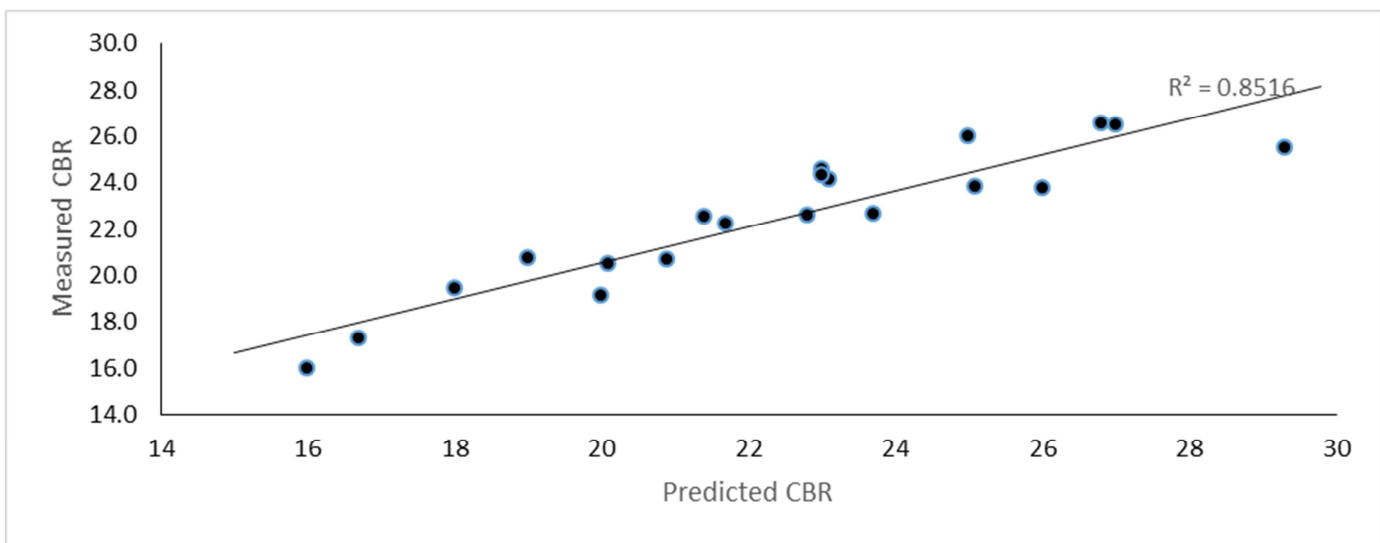

Figure 5. Validation plot of CBRmp $=19.5-0.836 \mathrm{Cm}-0.178 \mathrm{WG}-0.759 \mathrm{LL}+2.33 \mathrm{PL}-18.5 \mathrm{MDDmp}$.

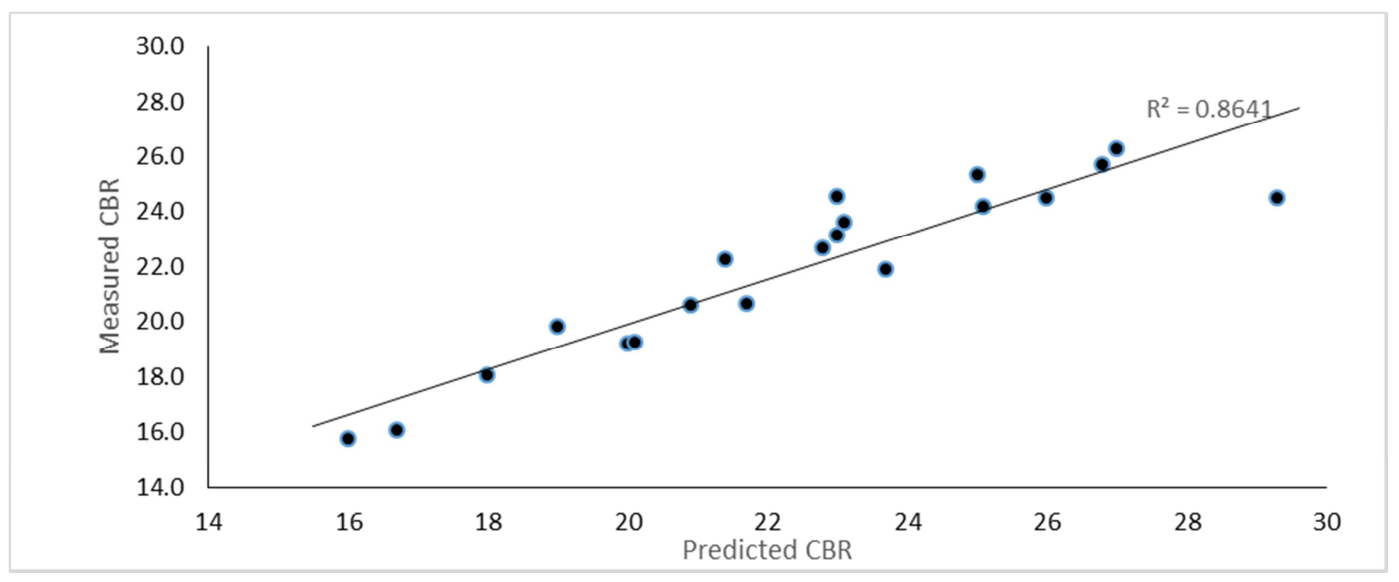

Figure 6. Validation plot of CBRmp $=151-1.05 \mathrm{Cm}-0.152 \mathrm{WG}+2.32 \mathrm{PL}-0.935 \mathrm{LL}-1.66$ OMCmp - 71.6 MDDmp.

\section{Conclusion}

Regression analysis correlating soaked CBR value with easily determined soil parameters was carried out on twenty (20) disturbed soil samples stabilized with (2-8\%) Ordinary Portland cement (OPC) and (5-20\%) WG blend at OMC. The CBR was used as the dependent variables, while MDD, WG, $\mathrm{Cm}, \mathrm{LL}$ and PL were used as independent variables and it was found that these independent variables for both compactive efforts and the prediction models of the soaked CBR is fairly close to the corresponding actual results.
Regression analysis estimation of these variable indicated strong correlations $\left(R^{2}=0.98\right.$ and 0.94$)$ for SP and MP respectively. It was shown that the correlation equations obtained as a result of regression analysis were in agreement with the test results and the model equations developed from this work provided a very good prediction of the response, as the equations can be employed for making estimates of soaked CBR of other black cotton soils having similar geotechnical properties. The equations are:

CBRsp $=108-0.464 \mathrm{Cm}-0.240 \mathrm{WG}-0.607 \mathrm{LL}+1.31$ PL - 1.47 OMCsp - 44.4 MDDsp $\quad\left(R^{2}=0.98\right)$ 
$\mathrm{CBRmp}=151-1.05 \mathrm{Cm}-0.152 \mathrm{WG}+2.32 \mathrm{PL}-0.935$

LL - 1.66 OMCmp - 71.6 MDDmp $\left(R^{2}=0.94\right)$

\section{References}

[1] Patel, M. A., and Patel, H. S. (2012). A review on effects of stabilizing agents for stabilization of weak soil. Civil and Environmental Research, 2 (6), 1-7.

[2] Ramasubbarao, G. V., \& Sankar, G. S. (2013). Predicting soaked CBR value of fine-grained soils using index and compaction characteristics. Jordan Journal of Civil Engineering, 7 (3), 354-360.

[3] Shirur, N. B., \& Hiremath, S. G. (2014). Establishing relationship between $\mathrm{CBR}$ value and physical properties of soil. IOSR journal of mechanical and civil engineering, 11 (5), 26-30.

[4] Satyanarayana Reddy, C. N. V., \& Pavani, K. (2006). Mechanically stabilised soils-regression equation for CBR evaluation. In Proceedings of the Indian geotechnical conference, Chennai, India (pp. 731-734).

[5] Gregory, G. H., \& Cross, S. A. (2007). Correlation of CBR with shear strength parameters. In Proceedings of 9th International Conference on Low Volume Roads, Austin, Texas

[6] Vinod, P., \& Reena, C. (2008). Prediction of CBR value of lateritic soils using liquid limit and gradation characteristics data. Highway Research Journal, IRC, 1 (1), 89-98.

[7] Patel, R. S., \& Desai, M. D. (2010). CBR predicted by index properties for alluvial soils of South Gujarat. In Proceedings of the Indian Geotechnical conference, Mumbai (pp. 79-82).

[8] Yildrim, B. and Gunaydin, O. (2011). Estimation of CBR by Soft Computing Systems, Expert Systems with Applications, ELSEVIER, 38 (5): 6381-6391.

[9] Patel, M. A., \& Patel, H. S. (2012). Experimental Study to Correlate the Test Results of PBT, UCS, and CBR with DCP on Various soils in soaked condition. International Journal of
Engineering (IJE), 6(5), 244.

[10] Venkatasubramanian, C., \& Dhinakaran, G. (2011). ANN model for predicting CBR from index properties of soils. International Journal of Civil \& Structural Engineering, 2 (2), 614-620.

[11] Sabat, A. K. (2013). Prediction of California bearing ratio of a soil stabilized with lime and quarry dust using artificial neural network. Electronic Journal of Geotechnical Engineering, 18, 3261-3272.

[12] Alawi, M., and Rajab, M. (2013). Prediction of California bearing ratio of sub-base layer using multiple linear regression models. Road Materials and Pavement Design, 14 (1), 211-219.

[13] Talukdar, D. K. (2014). A Study of Correlation between California Bearing Ratio (CBR) Values with Other Properties of Soil. International Journal of Emerging Technology and Advanced Engineering, 4 (1), 559-562.

[14] Ikara, I. A., Kundiri, A. M., \& Mohammed, A. (2015). Effects of Waste Glass (WG) on the Strength Characteristics of Cement Stabilized Expansive Soil. American Journal of Engineering Research (AJER), 4, 33-41.

[15] BS 1377 (1990). Methods of Testing Soils for Civil Engineering Purposes. British Standard Specification, London.

[16] BS 1924 (1990). Methods of Tests for Stabilized Soils. British Standard Specification. London.

[17] Ugbe, F. C. (2012). Predicting Compaction Characteristics of Lateritic Soil of Western Niger Delta, Nigeria. Research Journal of Environmental and Earth Sciences, 4 (5), 553-559.

[18] Alam MZ, Ameem ES, Muyibi SA, Kabbash NA (2009) the factors affecting the performance of activated carbon prepared from oil palm empty fruit bunches for adsorption of phenol. Chemical Engineering Journal doi: 10.106/J.cej.2009.07.033.

[19] Montgomery DC, Runger GC (2011) Applied statistics and probability for engineers. $5^{\text {th }}$ edn. Wiley and Sons, Asia, Pte, Ltd. 